\title{
Research of the Influence on the Modification of Beryllium in Al-Si Alloy
}

Iryna Hren, Štefan Michna, Liudmyla Drozdyk*, Jaromír Cais, Lenka Michnová, Jaroslava Svobodova, and Lubomír Hodinář

Jan Evangelista Purkyně University in Ústí nad Labem, Faculty of Production Technologies and Management,

1 Pasteurova Str., 40096 Ústí nad Labem, Czech Republic

"Yuriy Fedkovych Chernivtsi National University,

2 Kotsyubynsky Str.,

UA-58012 Chernivtsi, Ukraine

Modification of molten metal is performed for the eutectic and subeutectic silumins prior to its casting by using strontium, which has a time-limited effect up to 1-1.5 hours. Beryllium is used in order to prolong the modifying effect. The aim of the experiment is to examine both the distribution and the effect of beryllium in the structure on the temporary extension of the modification in the $\mathrm{Al}-\mathrm{Si}$ alloys in combination with strontium modifier. Beryllium is used as a master $\mathrm{AlBe}_{5}$ alloy, and samples are cast by gravity casting in a preheated metal moulding. Chemical analysis is performed by means of spectral analysis. Specimens are evaluated by using a confocal microscope. The elements' distribution in the $\mathrm{AlSi}_{7} \mathrm{Mg}_{0.3}$ alloy microstructure, with emphasis on the distribution of $\mathrm{Sr}$ and $\mathrm{Be}$ as the individual structural components, is investigated using a scanning electron microscope with EDS analyser.

Key words: $\mathrm{AlSi}_{7} \mathrm{Mg}_{0.3}$ alloy, modifier, beryllium, strontium, electron microscopy, EDS analysis.

Перед відливанням розтопленого металу виконується модифікування

Corresponding author: Liudmyla Drozdyk

E-mail: lydadrozduk@gmail.com

Citation: Iryna Hren, Štefan Michna, Liudmyla Drozdyk, Jaromír Cais,

Lenka Michnová, Jaroslava Svobodova, and Lubomír Hodinár, Research of the Influence on the Modification of Beryllium in Al-Si Alloy, Metallofiz. Noveishie Tekhnol., 40, No. 12: 1637-1647 (2018), DOI: 10.15407/mfint.40.12.1637. 
евтектичних і субевтектичних силумінів за допомогою Стронцію, який має обмежений 1-1,5 годинами тимчасовий ефект дії. Берилій використовується для продовження модифікувального ефекту. Метою експерименту є вивчення розподілу та впливу берилію в структурі на тимчасове подовження модифікувальної дії в стопах $\mathrm{Al}-\mathrm{Si}$ у поєднанні зі стронційовим модифікатором. Берилій використовувався у вигляді лігатурного стопу $\mathrm{AlBe}_{5}$, а зразки виливалися за допомогою методи гравітаційного лиття у попередньо нагріту металеву прес-форму. Хемічна аналіза проводилася за допомогою спектральної аналізи. Зразки оцінювали за допомогою конфокального мікроскопу. Розподіл елементів у мікроструктурі стопу $\mathrm{AlSi}_{7} \mathrm{Mg}_{0,3} 3$ акцентом на розподілі $\mathrm{Sr}$ i $\mathrm{Be}$ як окремих структурних компонентів було досліджено за допомогою сканувального електронного мікроскопу з аналізатором ЕДС.

Ключові слова: стоп $\mathrm{AlSi}_{7} \mathrm{Mg}_{0,3}$, модифікатор, берилій, стронцій, електронна мікроскопія, ЕДС-аналіза.

Перед отливкой расплавленного металла выполняется модифицирование эвтектических и субэвтектических силуминов с помощью стронция, который имеет ограниченный $1-1,5$ часами временный әффект воздействия. Бериллий используется для продления модифицирующего эффекта. Целью эксперимента является изучение распределения и влияния бериллия в структуре на временное продление модифицирующего воздействия в сплавах $\mathrm{Al}-\mathrm{Si}$ в сочетании со стронциевым модификатором. Бериллий использовался в виде лигатурного сплава $\mathrm{AlBe}_{5}$, а образцы отливали с помощью метода гравитационного литья в предварительно нагретую металлическую пресс-форму. Химический анализ проводился с помощью спектрального анализа. Образцы оценивались с помощью конфокального микроскопа. Распределение элементов в микроструктуре сплава $\mathrm{AlSi}_{7} \mathrm{Mg}_{0,3}$ с акцентом на распределении $\mathrm{Sr}$ и Ве как отдельных структурных компонентов исследовалось с помощью сканирующего электронного микроскопа с анализатором ЭДС.

Ключевые слова: сплав $\mathrm{AlSi}_{7} \mathrm{Mg}_{0,3}$, модификатор, бериллий, стронций, электронная микроскопия, ЭДС-анализ.

(Received January 21, 2018; in final version, September 19, 2018)

\section{INTRODUCTION}

Strontium is the most widely used modifier in the subeutectic and eutectic silumins. Strontium does not cause a permanent modification effect, which occurs over time in the melt to its firing, i.e., to drop the content of modification element and the modifying effect in 1-2 hours fading. The addition of strontium led to a clear conversion of eutectic silicon shape, when the place of already mentioned coarse hexagonal panels defines gently rounded rods. This one improves the strength characteristics of casting and, particularly, plasticity, but also technological properties, especially, castabil- 
ity and machinability.

The strontium is charged in the form of a pre-alloy, e.g., $\mathrm{AlSiI}_{3} \mathrm{Sr}_{10}, \mathrm{AlSr}_{10}$ or $\mathrm{SrCO}_{3}$. $\mathrm{Al}-\mathrm{Si}$ type alloys contain strontium in the $\mathrm{SrAl}_{4}$-type form. Ligature $\mathrm{Al}-\mathrm{Si}$ alloy contains strontium in the form of $\mathrm{SrAl}_{4}$-type particles. The quantity of the master alloy must be converted to the optimum amount of pure strontium that varies according to literal sources [1] in the range from 0.03 to $0.05 \%$. When exceeding the optimal amount of formed $\mathrm{Al}_{2} \mathrm{Si}_{2} \mathrm{Sr}$-type brittle phases, they are excluded in the segregation regions.

The strontium modification mechanism consists of following reactions [2]:

- breakdown of particles $\mathrm{SrAl}_{4}$;

- formation of new-phase $\mathrm{Al}_{2} \mathrm{Si}_{2} \mathrm{Sr}$ particles;

- re-decay $\mathrm{Al}_{2} \mathrm{Si}_{2} \mathrm{Sr}$ phase particles to form free $\mathrm{Sr}$;

- effect of free $\mathrm{Sr}$ in the manner of crystal growth of silicon in accordance with the theory of operation of surface active elements;

- Sr partial reaction with phosphorus (contained in the alloy as impurities from the starting materials) to give phosphorus strontium, which leads to downregulation modifying effect of strontium.

Many authors [2,3] argue that modifying strontium has the best effect on the casting process at a slow cooling rate.

The presented experiment is part of a larger research focusing on the study of structure and phase changes in the melt during the $\mathrm{Al}-\mathrm{Si}$ alloy casting with the addition of Sr modifiers and the extension of its particle inversion using beryllium. In this part of the experiment, the first part was to target the modifying effect of $\mathrm{Sr}$ in the $5 \mathrm{~min}, 30 \mathrm{~min}, 1 \mathrm{~h}$, and $2 \mathrm{~h}$ steps without the addition of beryllium, and in the second part of the experiment, $\mathrm{Sr}$ and $\mathrm{Be}$ were added to the melt and cast samples at intervals from one hour to 4 hours after addition of $\mathrm{Sr}$ and Be. In the next part of the experiment, structures of strontium alloys were prepared and then evaluated with the $\mathrm{Sr}$ and $\mathrm{Be}$ distributions in the structure by elemental EDS analysis on a scanning electron microscope.

For the experiment with $\mathrm{AlSi}_{7} \mathrm{Mg}_{0.3}$ alloy, adding a $\mathrm{Sr}$ modifier and ligature $\mathrm{AlBe}_{5}$ alloy was made. This material contains 92.7\% $\mathrm{Al}, 7 \% \mathrm{Si}$ and $0.3 \% \mathrm{Mg}$ (respectively, chemical composition of the alloy see in Table 1). The next step was the addition of a $\mathrm{Sr}$ modifier and prolong its efficiency with $\mathrm{Be}$. In this case, $\mathrm{Sr}$ is used as a

TABLE 1. The chemical composition of $\mathrm{AlSi}_{7} \mathrm{Mg}_{0.3}$ alloy.

Chemical composition [wt.\%]

\begin{tabular}{c|c|c|c|c|c|c|c|c|c}
\hline $\mathrm{Si}$ & $\mathrm{Fe}$ & $\mathrm{Cu}$ & $\mathrm{Mn}$ & $\mathrm{Mg}$ & $\mathrm{Cr}$ & $\mathrm{Zn}$ & $\mathrm{Pb}$ & $\mathrm{Ti}$ & $\mathrm{Al}$ \\
\hline $6.5-7.5$ & 0.17 & 0.05 & 0.1 & $0.25-0.45$ & - & 0.07 & - & $0.08-0.025$ & Residue \\
\hline
\end{tabular}


ligature $\mathrm{AlSr}_{10}$ with the addition of $0.04 \%$ modifier.

Beryllium is also added as a ligature $\mathrm{AlBe}_{5}$ alloy at a concentration of $0.20 \%$. In order to verify whether the extended modification, samples were cast after every hour up to four hours after addition of $\mathrm{Sr}$ and Be. Melting occurs at a temperature of $750-760^{\circ} \mathrm{C}$; using technology of gravity casting, the samples are left in the form until cool. The resulting castings have a conical shape with a height of $700 \mathrm{~mm}$, an upper diameter of $850 \mathrm{~mm}$, and a bottom diameter of $400 \mathrm{~mm}$.

\section{MICROSCOPIC EVALUATION OF THE STRUCTURE AND QUALITY OF THE MODIFICATIONS}

For the exploration of samples, confocal laser microscope Olympus LEXT OLS 3100 (Figs. 1-4) was used. Microstructure of subeutectic silumin without addition of strontium modifier is formed by dendritic cells of $\alpha$ phase and a eutectic phase, which is composed of $\alpha$ solid solution of silicon in the form of coarse hexagonal plates, which are in the plane of the metallographic cut and appear as irregular sharp needles of various sizes. For microstructures with the addition of strontium and without beryllium after 5 minutes, it is shown an optimum effect of the modification, wherein the eutectic silicon is precipitated as a perfect round or protracted grain (Fig. 1, a). In a sample after thirty minutes of the cast, the structure is no different from the previous sample, wherein the rounded grains are the eutectic silicon slightly elongated (Fig. 1,b). This testifies to the fact that the shape of the precipitated eutectic silicon begins to change from a rod or a fibre to the plate. The cause of the heel is a slowly starting to fade modifying effect of strontium [4].

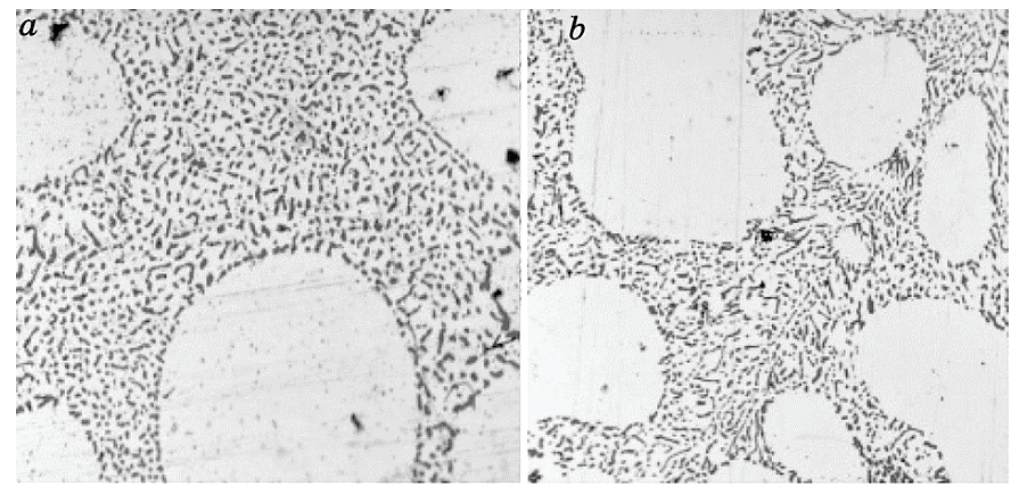

Fig. 1. Microstructure of $\mathrm{AlSi}_{7} \mathrm{Mg}_{0.3}$ alloy with $\mathrm{Sr}$ and without Be after 5 min $(a)$ and after 30 min $(b)$ of modification. 
A significant change is occurred in cast sample after one hour of modification. In the structure, eutectic silicon is no longer apparent

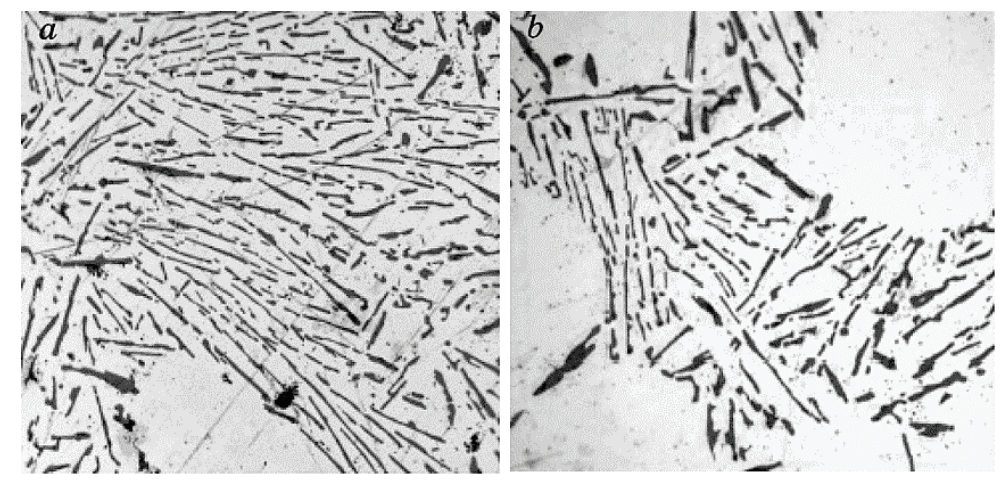

Fig. 2. Microstructure of $\mathrm{AlSi}_{7} \mathrm{Mg}_{0.3}$ alloy with $\mathrm{Sr}$ and without $\mathrm{Be}$ after 1 hour $(a)$ and after 2 hours $(b)$ of modification.

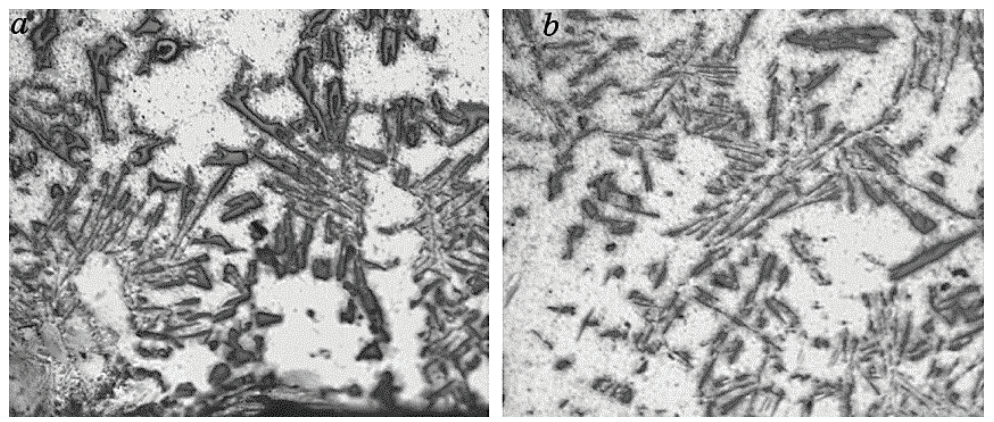

Fig. 3. Microstructure of $\mathrm{AlSi}_{7} \mathrm{Mg}_{0.3}$ alloy with $\mathrm{Sr}$ and Be after 1 hour (a) and after 2 hours $(b)$ of modification.

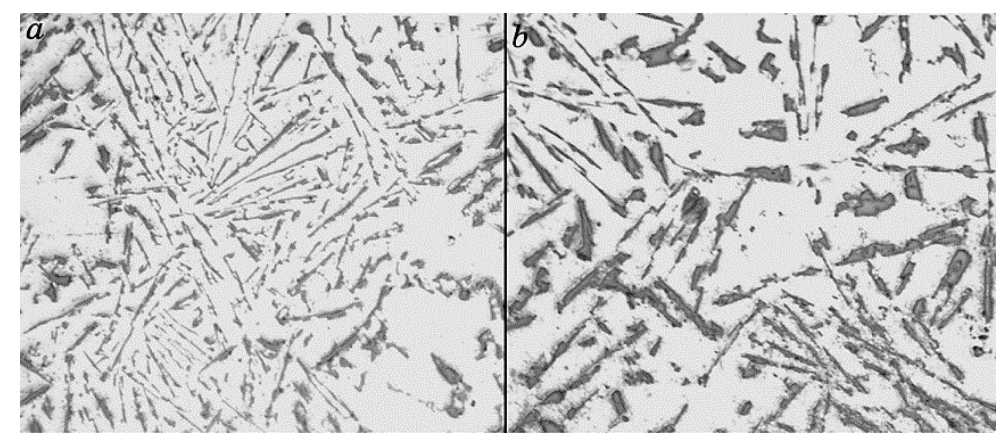

Fig. 4. Microstructure of $\mathrm{AlSi}_{7} \mathrm{Mg}_{0.3}$ alloy with $\mathrm{Sr}$ and Be after 3 hours (a) and after 4 hours $(b)$ of modification. 
as fine grains, but, instead, in the form of a partially curved needles (Fig. 2, a). This suggests that, in the alloy, modification effect is nearly disappeared, and a practical structure looks like unmodified. Therefore, it can conclude that the modifying effect of strontium is lost in time between half an hour and an hour after melt modification. For a sample of the cast, two hours after the modification, the structure shown has only coarse eutectic silicon needles (Fig. 2, $b$ ).

After adding strontium to the original material, eutectic silicon is increased to needle size that has the effect of widening plates of eutectic stages, and there is a merger of several thin plates, which produce a long needle Si phase.

Linearly with modifiers' action, there is a coarsening of the eutectic silicon needles with reducing the distance between them (Fig. $3, a, b)$.

Due to the addition of beryllium, the modifying effect is prolonged throughout the experiment during 4 hours (Fig. 4). Morphology of the particles of eutectic silicon (rounded particles) is observable in all examined samples.

Based on the examination of the microstructure by scanning electron microscope, we showed the presence of strontium on the surface of the eutectic silicon particles. This confirms used literature sources, which describe the modification of $\mathrm{Al}-\mathrm{Si}$ alloys with $\mathrm{Sr}$, which, during crystallization process, as surfactant binds crystallizing nuclei of eutectic silicon to supply the other silicon atom. This fact consequently significantly affects the final particle morphology of silicon.

\section{SCANNING ELECTRON MICROSCOPY AND EDS ANALYSIS}

When examining the microstructure of a sample of the alloy by scanning electron microscopy methods, Tescan VEGA3 electron microscope was used. The chemical composition of structural components excluded in the microstructure was determined with the help of energy dispersive spectrometry (EDS) analyser by Bruker. Figure 5 is indicated the area where strontium was found. Elemental maps, which confirm the identification of $\mathrm{Sr}$ on the surface of silicon particles, are indicated in Fig. 6, $a, b$.

Elemental maps of the $\mathrm{Si}$ and $\mathrm{Sr}$ distribution show that, on the surface of the silicon particles, there are particles of strontium, and these findings are also confirmed by EDS across the board in the area.

Quantification of the results of the designated area is shown in Table 2, wherein the recording sheet from the EDS analysis carried out is shown in Fig. 7. 
After a further period of modifications, beryllium was detected only in the two samples, in addition after 4 hours of modification.

Surface EDS analysis confirmed that beryllium extends in solid solution, as shown in Fig. 8 and indicated by a cross. Recording sheet of EDS analysis of the surface is designated in Fig. 9. Results

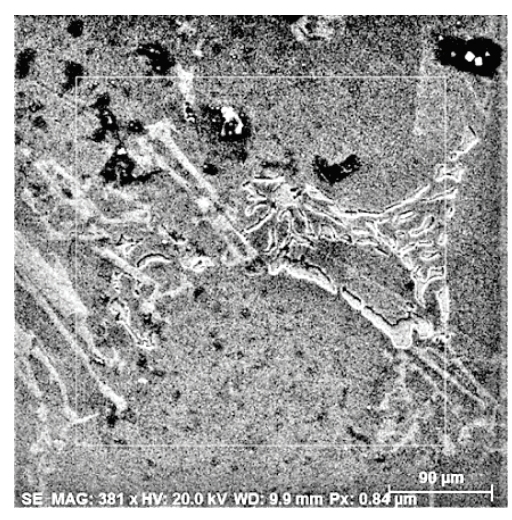

Fig. 5. Microstructure of example after 4 hours of modification.

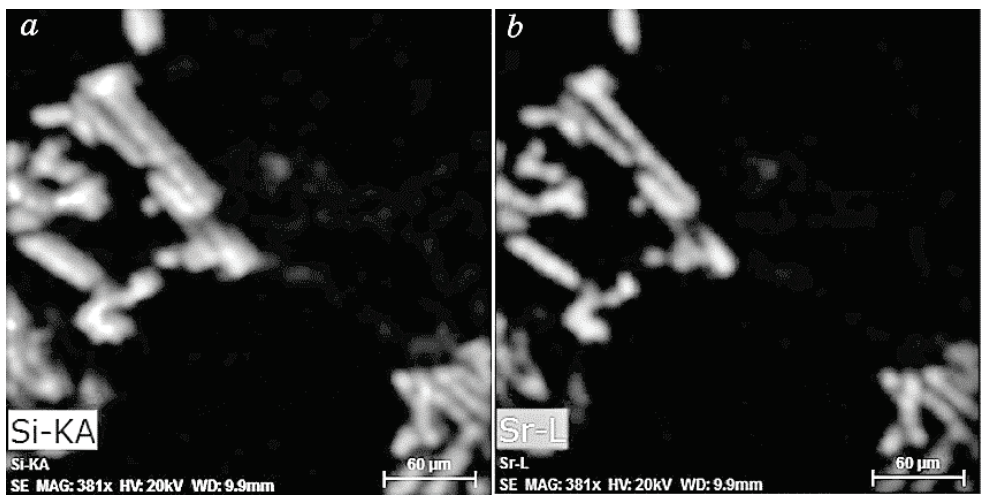

Fig. 6. Primary maps of the $\mathrm{Si}(a)$ and $\mathrm{Sr}(b)$ atoms' distribution on the surface of the $\mathrm{AlSi}_{7} \mathrm{Mg}_{0.3}$ alloy.

TABLE 2. Quantification of the results' sheet of EDS analysis.

\begin{tabular}{c|c|c}
\hline Element & Concentration [wt.\%] & Concentration [at.\%] \\
\hline Aluminium & 55.76 & 58.63 \\
Silicon & 39.41 & 39.80 \\
Strontium & 4.83 & 1.56 \\
Total & 100.00 & 100.0 \\
\hline
\end{tabular}




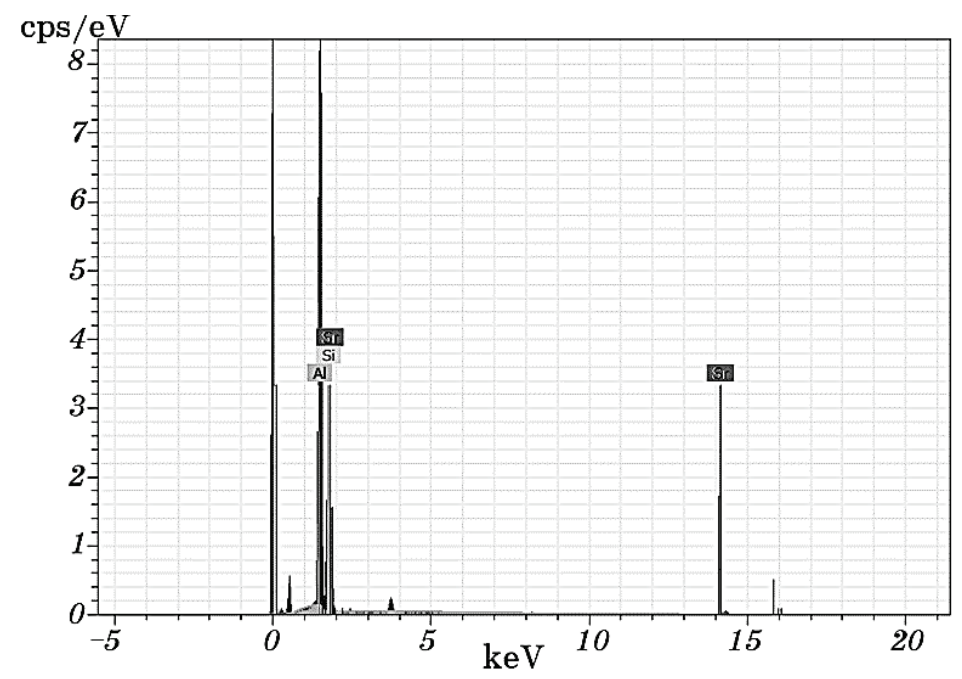

Fig. 7. Recording sheet of EDS analysis.

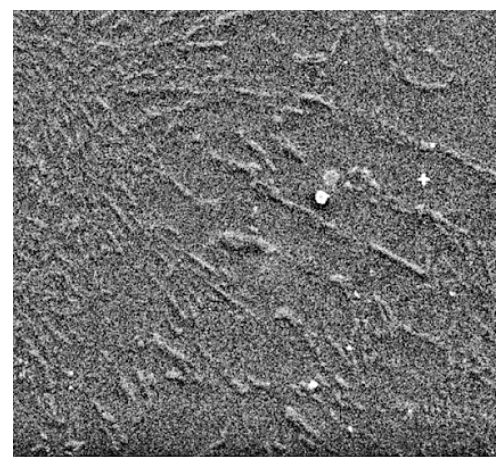

Fig. 8. Microstructure of example after 4 hours of modification.

of quantification of surface EDS are recorded in Table 3.

Compared with one another in the area captured with beryllium and strontium, it is found that both elements are excreted in the same location as shown in Fig. 10. This indicates that beryllium and silicon are bound together with strontium, thereby, extending its modification capability over time.

\section{CONCLUSION}

The aim of the experiment was to examine the distribution and the effect of beryllium in combination with strontium in the structure on a modification in the AlSi alloys. 


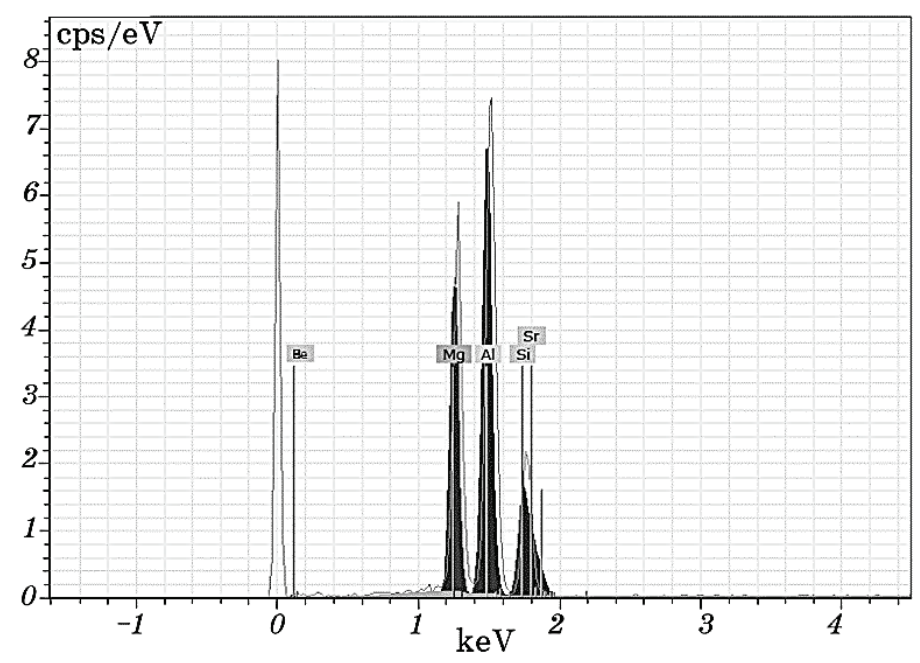

Fig. 9. Recording sheet of EDS analysis.

TABLE 3. Quantification of the results' sheet of EDS analysis.

\begin{tabular}{c|c|c}
\hline Element & Concentration [wt.\%] & Concentration [at.\%] \\
\hline Aluminium & 97.28 & 96.43 \\
Silicon & 1.05 & 1.16 \\
Magnesium & 1.26 & 1.20 \\
Beryllium & 0.41 & 1.21 \\
Strontium & 0.38 & 0.12 \\
Total & 100.00 & 100.0 \\
\hline
\end{tabular}

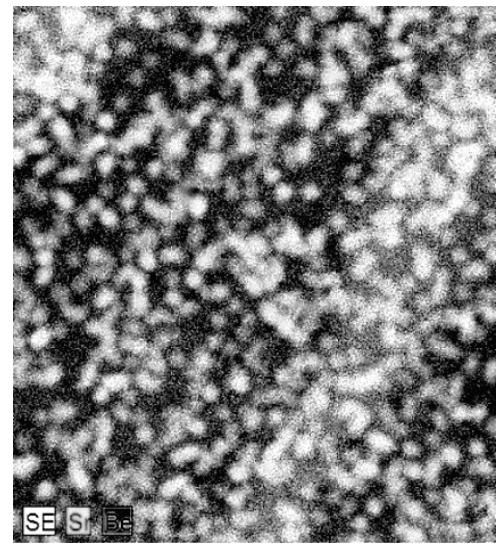

Fig. 10. EDS maps of the Be and $\mathrm{Sr}$ atoms on the surface of the $\mathrm{AlSi}_{7} \mathrm{Mg}_{0.3}$ alloy. 
In the context of the experiment, 15 samples of microstructural examination were tested, and the influence of beryllium on a modified $\mathrm{Al}-\mathrm{Si}$ alloy is determined.

As observed with alignments of the modified and unmodified alloys, there are significant differences in the resulting particle morphology silicon.

Microscopic evaluation confirmed that the silicon needles after half an hour began to stretch and create spatially needles as plates.

Between half an hour and an hour, modifying effects of strontium gradually diminish over time. To continue to run modification, the master $\mathrm{AlBe}_{5}$ alloy was used, thus, extending the modifying effect of strontium up to 4 hours.

In the microstructure of the investigated alloy, beryllium was found in small quantities.

It is not confirmed the assertion of various authors to establish strontium and main beryllium only on the silicon surface.

The microstructure of the cast alloy with beryllium and strontium was detected on needle eutectic silicon, where beryllium is linked to strontium, thus, prolonging the modification. Beryllium has also been found to spread evenly in the solid solution between the dendritic cells, thereby, preventing the disintegration of, probably, $\mathrm{SrAl}_{4}$ intermetallic phases, and thereby, prolongs the disintegration time of strontium.

\section{ACKNOWLEDGEMENT}

This contribution was created under the support of project SG $4820215000401 / 2016$ at UJEP.

\section{REFERENCES}

1. D. Bolibruchova and E. Tillova, Cast Alloys Al-Si (ZU: EDIS: 2005).

2. S. Michna, I. Lukas, V. Ochenachek, R. Koreny, J. Drapala, H. Schneider, and A. Mishkufova, Encyclopedia of Aluminum (Preshov: Adin: 2005).

3. L. F. Mondolfo, Aluminium Alloys: Structure and Properties (London: Butterworths: 1979).

4. D. Suchanek and K. Dusak, Impact of Cutting Conditions on Tool Wear, 16, No. 5: 33 (2011).

5. Plachy, M. Nemec, and B. Bednar, Theory of Casting (Prague: CTU: 2002).

6. S. Michna and I. Nova, Technology and Processing of Metallic Materials (Preshov: Adin: 2008).

7. U. Hideyuki et al., Cast Metals, 8, No. 1: 7 (1995).

8. N. Naprstkova, J. Cais, and J. Svobodova, Manufacturing Technology, 18: No. 4, 265 (2013).

9. V. Weiss and J. Svobodova, Manufacturing Technology, 15, No. 6: 1048 
(2015).

10. N. Naprstkova, J. Cais, and J. Svobodova, Manufacturing Technology, 13, No. 3: 380 (2013).

11. E. Tillova, M. Chalupova, L. Hurtalova, and E. Durinikova, Manufacturing Technology, 11, No. 11: 70 (2011).

12. A. Dugin and A. Popov, Manufacturing Technology, 13, No. 2: 169 (2013). 